\title{
Effects of Marketing Models and Service Quality on Customer Repurchase Intentions: Evidence from Taiwan's Life Insurance Industry \\ Tseng-Chung Tang
}

Department of Business Administration

National Formosa University

Taiwan

\section{Li-Chiu Chi}

Department of Applied Foreign Languages

National Formosa University

Taiwan

\section{Hsu-Tong Deng}

Department of Business Administration

Jinwen University of Science \& Technology

Taiwan

\section{Yue-Ling Li}

Graduate Institute of Business and Management

National Formosa University

Taiwan

\section{ABSTRACT}

In this study, we investigated the effects of marketing models and service quality on customer repurchase intentions by utilizing survey questionnaires and using life insurance as the product being studied. The sample consisted of 400 customers who responded to an anonymous 34-item, five-point Likert scale questionnaire. The hypotheses were tested and all of them were supported by the data; hence, there are a significant relationship among marketing models, service quality, and customer repurchase intentions. Specifically, although marketing models and service quality are both significantly positively related to repurchase intentions, repurchase intentions correlated more strongly with service quality than with marketing models. Moreover, we found evidence that both marketing models and service quality can significantly predict repurchase intentions. The research results have both theoretical and practical implications.

\section{KEYWORDS: Marketing Model; Service Quality; Repurchase Intention; Life Insurance}

\section{Introduction}

With economic growth, social changes, and the improvement of education, people are more knowledgeable and can better understand the importance as well as the need for insurance. With the popularization of insurance, the public finds importance and value in the protective function of insurances which prompts the public to purchase them. According to Article 13 of the Taiwan Insurance Law, "Insurance is divided into life insurance and property insurance. The former includes life insurance, health insurance, injury insurance, and annuity insurance." Life insurance is indispensable basic indemnification protection in modern society and with life insurance companies throughout Taiwan competing with each other, various life insurance products are constantly updated and improved. Recent data from the Sigma Research of Swiss Re-insurance Institute (2020) show that
Taiwan's life insurance penetration in 2019 reached 18.34\%, ranking first in the world for 13 consecutive years, and the life insurance density was US\$5,233, ranking fourth in the world.

As the life insurance industry is a part of the service industry, product marketing is required. Life insurance marketing refers to the operating process in which insurance companies use different types of techniques and strategies for selling and marketing life insurance products (Sharma \& Patterson,1999). Due to the professional services that are characterized by intangibility, inseparability, complexity, customization, and perishability, the life insurance industry develops and applies the required marketing strategies regarding each of these characteristics (Reza \& Iqbal,2007). All of the insurance companies in Taiwan, to some extent, are accustomed to relying heavily on various personal distribution systems such as the sales force of insurance companies, 
insurance agents, and insurance brokers to stimulate consumer purchase intentions. Put simply, the majority of life insurance policies sold are through personal distribution systems (Ericson \& Doyle,2006).

Marketing in the recent decade has proved to be everchanging and complicated due to the changing perceptions of taste and fashion. Factors affecting marketing efficacy and purchase decisions have long been an interest of practitioners and academics alike. Research has shown that service quality is crucial for the survival of insurance companies and that customer dissatisfaction toward the insurance companies largely stems from the inferior quality of services (Cooper \& Frank,2001). The quality of after-sales services, in particular, can result in very positive results through customer loyalty, repetitive sales, and cross-selling (Taylor, 2001; Siddiqui \& Sharma,2010). Numerous researches have been made theoretically or empirically to contribute to the body of literature on service quality and purchase intentions; however, there is little in the literature that examines the relationship between marketing models and service quality as well as the relationship between marketing models and repurchase intentions in the area of life insurance. Given that the insurance industry has always stressed the importance of satisfying customer needs and providing quality services, this study seeks to expand on previous research by investigating the relationships among marketing models, service quality, and customer repurchase intentions from the life insurance repurchase perspective.

The remainder of this paper is divided into four sections. Section 2 provides a brief literature review. Section 3 lays out the subjects and sampling procedure, instrumentation, and the validity and reliability of instruments. Section 4 presents the empirical results. Section 5 summarizes the implications of results and then offers concluding comments.

\section{Literature Review}

\subsection{Models of Life Insurance Marketing}

According to the American Marketing Association (AMA, 2004), marketing is an organizational function and a set of processes for creating, communicating, and delivering value to customers and for managing customer relationships in ways that benefit the organization and its stakeholders. Marketing is the primary link between companies and their customers; hence, marketing positions and marketing models should be seriously considered by managers. The marketing model or marketing mix is the combination of marketing strategies and activities that companies use to sell their goods and services (Wheelen \& Hunger,2008). The marketing model includes the traditional 4P marketing mix (product, price, place, and promotion), or the expanded 7 P's of product, price, place, promotion, people, process, and physical environment. Insurance companies deal in selling services and therefore due weightage in the formation of marketing models is needed. Marketing people have involved in marketing different types of entities: goods, services, experiences, events, persons, places, properties, organizations, information, and ideas (Reza \& Iqbal, 2007). Accordingly, the marketing of insurance will fall into the category of service marketing among these entities.

Reza and Iqbal (2007) propose that there are five service levels of life insurance marketing: core benefit, basic services, expected services, augmented services, and potential services. Marketing systems refer to various methods of selling and marketing insurance products. Distribution systems for the sale of life insurance have changed dramatically over time. Major life insurance systems consist of personal selling systems, financial institution distribution systems, and the direct response system. For the distribution channels of life insurance, the most common and effective one is the personal distribution systems such as the sales force of insurance companies, insurance agents, and insurance brokers, while the direct response system is a marketing system through which life insurance products are sold directly to consumers without a face-to-face meeting with an agent; potential customers are solicited by Internet, television, radio, mail, newspaper, etc. (Duncan \& Moriarty, 1998).

\subsection{Service Quality}

Service refers to the policies, practices, and procedures of enterprises for the delivery of their tangibles (products) or intangibles (experiences) to customers (Schneider,1994). Since Regan deduced the characteristics of services in 1963, services have been considered not easy to be calculated or measured, and are difficult to be tested and verified. Researchers generally believe that services are characterized by intangibility, heterogeneity, inseparability, and perishability (refer to Regan, 1963; and Zeithaml, Parasuraman, \& Berry, 1985 for more details). Due to the special feature of services, many scholars agree that the evaluation and measurement of service quality is indeed an important research topic (Zeithaml \& Bitner,2003; Liao, Tang, \& Chi,2017).

The service quality is defined as an attitude, which is a comparison before and after receiving service (Parasurman, Zeithamal, \& Berry,1988; Tang, Chi, \& Tsai, 2020). Lewis and Booms (1983) deem service quality to be the coincidence between service provided and expected and that both should be consistent. Liao, Tang, and Chi (2017) describe that service quality is based on viewpoints of customers rendering to an evaluation consumer made after comparing service they expected and received and claim that service quality plays a critical role in the success of a business.

For assessing customer perceptions of service quality, Parasurman, Zeithamal, \& Berry (1988) constructed a multipleitem scale (SERVQUAL) covering five service quality dimensions of tangibles, reliability, responsiveness, assurance, and empathy. The SERVQUAL has been used widely in various service organizations and industries to measure service quality. 


\subsection{Repurchase Intentions}

In a service context, repurchase intentions are defined as "the individual's judgment about buying again a designated service from the same company, taking into account his or her current situation and likely circumstances (Hellier et al.,2003, p.1764)." The term is also defined as the customers' desire to buy a brand again in anticipation that they will gain the same or better value from the purchase (Louro, Pieters, \& Zeelenberg,2005). Repurchase intentions, being one of the five components of behavioral intentions, represent the customer's self-reported likelihood of engaging in further repurchase behavior (Zeithaml et al.,2003; Seiders et al.,2005).

Kotler (2000) argued that consumers will feel satisfied or dissatisfied to a certain extent after purchasing the service. If consumers are satisfied with the service, they will repeat the purchase and show brand loyalty, but if not satisfied, they may switch to other brands of services next time. Accordingly, satisfaction or dissatisfaction is considered the result of either confirmation or disconfirmation of prior expectations and is viewed as the major determinant of repurchase intentions (Jones, Mothersbaugh, \& Beatty,2000). While there are studies that indicate the positive relationship between customer satisfaction and repurchase intentions (Jones, Mothersbaugh, \& Beatty,2000; MacDonald \& Sharp, 2000; Taylor,2001), there are other studies that question such a relationship (Seiders et al., 2005; Kim, 2011). Some studies conducted on determining the basic antecedent variables to repurchase intention, while other studies considered the predictive validity of repurchase intention for subsequent repurchase behavior (Hellier et al., 2003).

\section{Methodology}

\subsection{Research Framework}

The research framework is as shown in Figure 3.1:

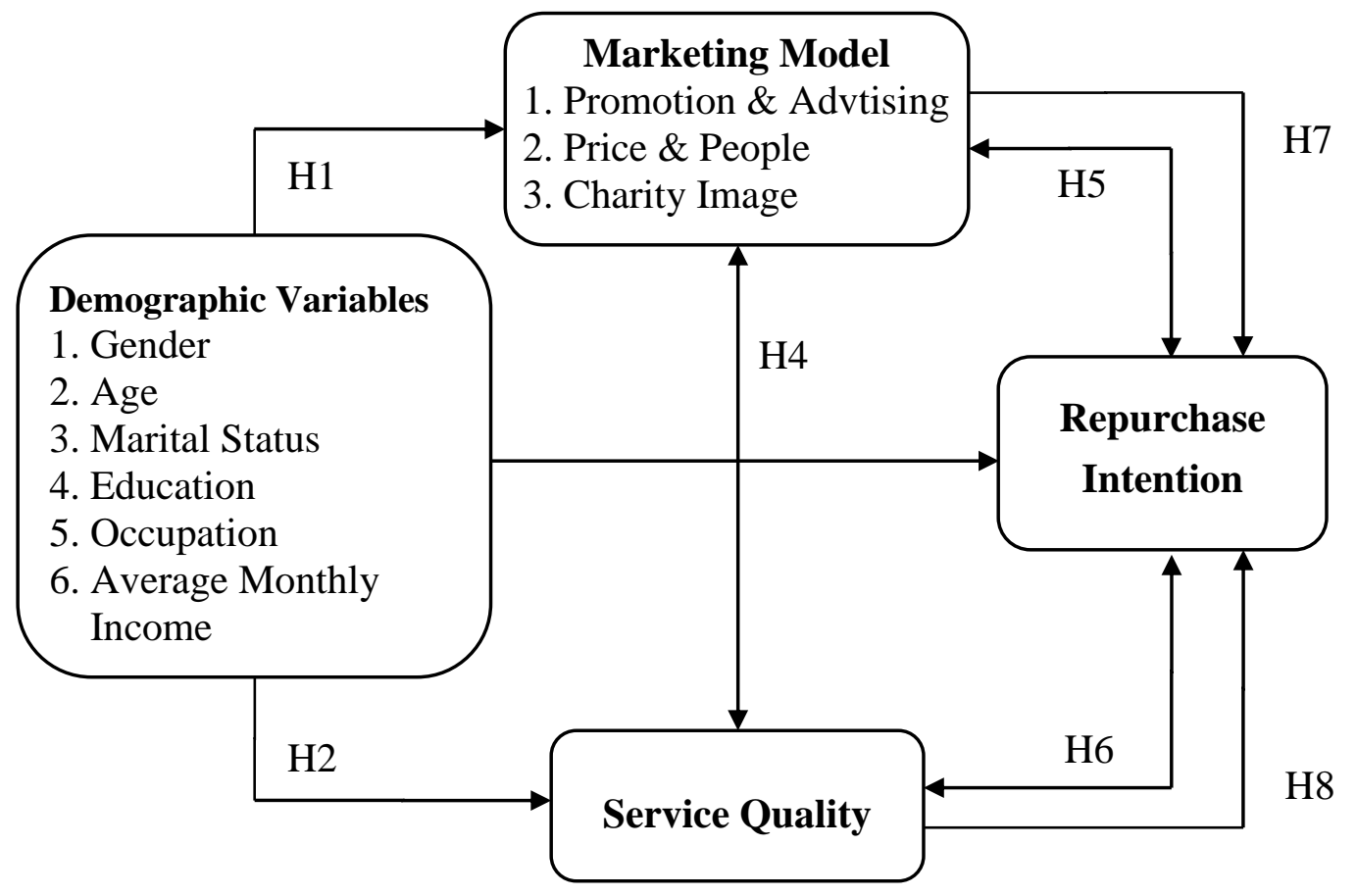

Figure 3.1 Research Framework

\subsection{Hypotheses}

The purpose of this study is to investigate the effects of marketing models and service quality on repurchase intentions. After reviewing the relevant literature, the hypotheses for the study are constructed as follows:

H1: Customers of different demographic variables show significant differences in the perception of marketing models.

H2: Customers of different demographic variables show significant differences in the perception of service quality.
H3: Customers of different demographic variables show significant differences in repurchase intentions.

H4: Marketing models and service quality are positively correlated.

H5: Marketing models and repurchase intentions are positively correlated.

H6: Service quality and repurchase intentions are positively correlated.

H7: Marketing models have a positive predictive power on repurchase intentions. 
H8: Service quality has a positive predictive power on repurchase intentions.

\subsection{Methodology}

\subsubsection{Subjects and Procedure}

We utilized the survey questionnaire and used life insurance as the product being studied. A convenience sampling technique was used to gather information for the study. Respondents were identified as suitable candidates for participation in this study if they met the eligibility criteria that they were over 20 years of age and had purchased at least one life insurance product. Anonymous questionnaires were given to 500 participants living in Taiwan in May 2020. A total of 400 questionnaires were used for the analysis of the data $(80 \%$ recovery rate).

\subsubsection{Instrumentation}

The questionnaire consisted of four parts. Part I, Part II, and Part III consisted of multiple questions relating to marketing models (13 items), service quality (15 items), and repurchase intentions (5 items), respectively, and Part IV gathered demographic data. In this study, three instruments Marketing Model Scale (MMS), Service Quality Scale (SQS), and Repurchase Intention Scale (RIS) were used. The questionnaire was designed based on a five-point Likert scale and was adopted from previous studies with high levels of reliability (Cronbach's $\alpha$ above 0.7). The Kaiser-Meyer Olkin (KMO) and Bartlett's Test measure of sampling adequacy were used to examine the appropriateness of Factor Analysis. The sample is adequate if $\mathrm{KMO}$ value is more than 0.7 , and is inadequate if less than 0.5; the $p$-value from Bartlett's Test of Sphericity should be statistically significant $(p<0.05)$ (Pallant,2007). To analyze common characteristics and construct validity, the principal component factor analysis with Varimax orthogonal rotation was performed. The minimum factor loading cut-off point for this study was 0.4 (Chan \& Idris, 2017).

\subsubsection{Validity and Reliability of Instruments}

The results for the KMO index and Bartlett's sphericity test for the MMS $\left(\mathrm{KMO}=0.908 ; \chi^{2}=2894.926, p<\right.$ $0.001)$, SQS $\left(\mathrm{KMO}=0.957 ; \chi^{2}=3898.569, p<0.001\right)$, and RIS (KMO $=0.883 ; \chi^{2}=1101.223, p<0.001$ ) were excellent, allowing for further testing with the factor analysis which indicated that the items in the MMS were grouped into three factors, Promotion \& Advertising (5 items), Price \& People (6 items), and Charity Image (2 items), with eigenvalues over Kaiser's criterion of 1 and together they explained $63.73 \%$ of the variance. The reliability of each of the three factors and the total score for the MMS were calculated using Cronbach's $\alpha$ coefficient and the following results were found: Promotion \& Advertising $=0.848 ;$ Price $\&$ People $=0.860 ;$ Charity Image $=$ 0.877 ; Total score $=0.915$. Moreover, the results showed that both the SQS $(\alpha=0.945)$ and RIS $(\alpha=0.893)$ contained only one factor, and the amount of explained variance was $56.99 \%$ and $70.26 \%$, respectively. Results from the Reliability
Analysis indicated that all of the Cronbach's $\alpha$ for the three scales were above 0.8 , ranging from 0.848 to 0.945 . These results showed that the instruments met the validity and reliability criteria (Pallant, 2007; Chan \& Idris, 2017).

In addition to Factor Analysis and Reliability Analysis, the data collected from the instruments were analyzed using the SPSS software for descriptive statistics, independent sample $t$ test, One Way Analysis of Variance, Pearson Product-Moment Correlation, and Regression Analysis.

\section{Analysis and Results}

\subsection{Results of Descriptive Analysis}

In this empirical study, participants were 400 adults who had purchased at least one life insurance product, aged between 20 and 65 years, $220(55 \%)$ were male and $180(45 \%)$ were female. Most received a bachelor's degree $(\mathrm{n}=158$; $39.5 \%)$, worked in the service industry $(\mathrm{n}=66 ; 16.5 \%)$, and were unmarried $(n=250 ; 62.5 \%)$.

Descriptive statistics of the marketing model (MM) dimension was measured with 13 items. In this part, the highest score of MMS defines the highest degree of recognition among the marketing models. MM4 was an item that had the highest score which indicated "The life insurance representative will take the initiative to explain to me the benefits of buying insurance products (Mean $=4.10 ; \mathrm{SD}=$ 0.736)." Whereas MM1 with "The content of the poster of the insurance company can attract my attention" was the item that had the lowest score (Mean = 3.64; SD = 0.845).

Descriptive statistics of service quality dimension was measured with 15 items. The highest score of SQS represents the best service quality. The highest score was SQ14: "The service of the life insurance representative is cordial and friendly, willing to help customers (Mean = 4.18; $\mathrm{SD}=0.708)$." The lowest score was for SQ2: "The life insurance company will actively offer excellent after-sales service $($ Mean $=3.91 ; \mathrm{SD}=0.848)$."

Descriptive statistics of repurchase intention (RI) dimension was measured with 5 items. The highest score of RIS expresses the highest repurchase intention level by insurance policyholders. The highest score was RI5: "If necessary, I will take the initiative to ask the insurance company for other insurance products (Mean $=3.98 ; \mathrm{SD}=$ 0.822)." The lowest score was for RI2: "If the insurance company launches new products, I will want to buy (Mean = 3.74; $\mathrm{SD}=0.851)$."

\subsection{Results of Difference Analysis}

Tables 4.1-4.3 summarize the analysis results of hypotheses test regarding the difference in perceptions of the marketing model, service quality, and repurchase intention by customers of different demographic variables. On difference analyses, no consistent significant associations were found between the scores of marketing models, service quality, or repurchase intentions and any of the following demographic factors: gender, age, marital status, educational level, or 
occupation, except for average monthly income. That is, there marketing models, service quality, and repurchase intentions, was a significant association between monthly income and respectively.

Table 4.1 Results of hypotheses test of marketing models for customers of different demographic variables

\begin{tabular}{|c|l|}
\hline \multicolumn{1}{|c|}{ Research Hypothesis } & \multicolumn{1}{|c|}{ Results } \\
\hline $\begin{array}{c}\text { H1-1: Customers of different genders show significant differences in the perception of } \\
\text { marketing models }\end{array}$ & Not Supported \\
\hline $\begin{array}{c}\text { H1-2: Customers of different ages show significant differences in the perception of marketing } \\
\text { models }\end{array}$ & Supported \\
\hline $\begin{array}{c}\text { H1-3: Customers of different marital status show significant differences in the perception of } \\
\text { marketing models }\end{array}$ & Not Supported \\
\hline $\begin{array}{c}\text { H1-4: Customers of different education show significant differences in the perception of } \\
\text { marketing models }\end{array}$ & Supported \\
\hline $\begin{array}{c}\text { H1-5: Customers of different occupations show significant differences in the perception of } \\
\text { marketing models }\end{array}$ & Supported \\
\hline $\begin{array}{c}\text { H1-6: Customers with different average monthly income show significant differences in the } \\
\text { perception of marketing models }\end{array}$ & Supported \\
\hline
\end{tabular}

Table 4.2: Results of hypotheses test of service quality for customers of different demographic variables

\begin{tabular}{|c|l|}
\hline \multicolumn{1}{|c|}{ Research Hypothesis } & \multicolumn{1}{|c|}{ Results } \\
\hline $\begin{array}{c}\text { H2-1: Customers of different genders show significant differences in the perception of service } \\
\text { quality }\end{array}$ & Not Supported \\
\hline $\begin{array}{c}\text { H2-2: Customers of different ages show significant differences in the perception of service } \\
\text { quality }\end{array}$ & Not Supported \\
\hline $\begin{array}{c}\text { H2-3: Customers of different marital status show significant differences in the perception of } \\
\text { service quality }\end{array}$ & Not Supported \\
\hline $\begin{array}{c}\text { H2-4: Customers of different education show significant differences in the perception of } \\
\text { service quality }\end{array}$ & Not Supported \\
\hline $\begin{array}{c}\text { H2-5: Customers of different occupations show significant differences in the perception of } \\
\text { service quality }\end{array}$ & Not Supported \\
\hline $\begin{array}{c}\text { H2-6: Customers with different average monthly income show significant differences in the } \\
\text { perception of service quality }\end{array}$ & Supported \\
\hline
\end{tabular}

Table 4.3 Results of hypotheses test of repurchase intentions for customers of different demographic variables

\begin{tabular}{|l|l|}
\hline \multicolumn{1}{|c|}{ Research Hypothesis } & \multicolumn{1}{c|}{ Results } \\
\hline H3-1: Customers of different genders show significant differences in repurchase intentions & Not Supported \\
\hline H3-2: Customers of different ages show significant differences in repurchase intentions & Not Supported \\
\hline H3-3: Customers of different marital status show significant differences in repurchase intentions & Not Supported \\
\hline H3-4: Customers of different education show significant differences in repurchase intentions & Not Supported \\
\hline H3-5: Customers of different occupations show significant differences in repurchase intentions & Not Supported \\
\hline $\begin{array}{l}\text { H3-6: Customers with different average monthly income show significant differences in } \\
\text { repurchase intentions }\end{array}$ & Supported \\
\hline
\end{tabular}

\subsection{Results of Correlation Analysis}

The results of this study found that the independent variables underlying this study are all correlated to the dependent variables. From the results of the Pearson productmoment correlations (refer to Table 4.4), this study reveals that (a) all the factors of marketing models and service quality have a significantly positive correlation with each other (fell within a moderate to strong correlation range, with Pearson's $r$ range of 0.523-0.729), (b) all the factors of marketing model and repurchase intentions have a positive correlation with each 


\section{(C) Center for Promoting Education and Research (CPER) USA}

other (within a weak to strong correlation range, with $r$ range of 0.487-0.729), and (c) service quality and repurchase intentions have a positive correlation with each other (strong correlation, $r=0.730$ ). Together, these results showed that while both marketing models and service quality are significantly positively related to repurchase intentions, repurchase intentions correlated more strongly with service quality than with marketing models. As such, Hypotheses 4, 5, and 6 were supported in these data. Table 4.5 shows a summary results of the correlation analysis among marketing models, service quality, and repurchase intentions.

Table 4.4 Results of correlations between variables and factors

\begin{tabular}{lccccc}
\hline & 1 & 2 & 3 & 4 & 5 \\
\hline \hline 1. Promotion \& & & & & & \\
Advertising & & & & & \\
2. Price \& People & $0.714^{* *}$ & & & & \\
3. Charity Image & $0.523^{* *}$ & $0.550^{* *}$ & & & \\
4. Service Quality & $0.607^{* *}$ & $0.729^{* *}$ & $0.576^{* *}$ & & \\
5. Repurchase Intentions & $0.636^{* *}$ & $0.629^{* *}$ & $0.487^{* *}$ & $0.730^{* *}$ & \\
\hline
\end{tabular}

Note: $* * p<0.01$

Table 4.5 Summary of results of correlation analysis

\begin{tabular}{|l|l|}
\hline \multicolumn{1}{|c|}{ Research Hypotheses } & Results \\
\hline H4: Marketing models and service quality are positively correlated & Supported \\
\hline H5: Marketing models and repurchase intentions are positively correlated & Supported \\
\hline H6: Service quality and repurchase intentions are positively correlated & Supported \\
\hline
\end{tabular}

4.4 Results of Regression Analysis of Marketing Models, Service Quality, and Repurchase Intentions

The regression results summary is shown in Tables 4.6 and 4.7. All models were statistically significant $(p<0.05)$ and a total of two regression equations are reported here. The regression analysis gives a more robust result than that obtained from the correlation run. All the regression coefficients were positive, indicating that customers had a higher level of repurchase intentions when they recognized more impressive marketing models or perceived better service quality. Additionally, three marketing model factors, Promotion $\&$ Advertising $(\mathrm{B}=0.375, p<0.00)$, Price \& People $(\mathrm{B}=$
$0.355, p<0.00)$, and Charity Image $(\mathrm{B}=0.123, p<0.00)$, and overall service quality $(\mathrm{B}=0.894, p<0.00)$ were statistically significant, suggesting that these variables/factors may predict repurchase intentions significantly (supporting H7: Marketing models have a positive predictive power on repurchase intentions and H8: Service quality has a positive predictive power on repurchase intentions). These results indicate that the independent variables have a significant impact on the dependent variables.

The data in Table 4.6 (Table 4.7) also show that $\mathrm{R}$ Square is equal to $0.479(0.533)$, indicating that $47.9 \%$ $(53.3 \%)$ of variation in repurchase intentions can be described by marketing models (service quality).

Table 4.6 Regression results of the effect of marketing models on repurchase intentions

\begin{tabular}{ll}
\hline Independent variables & $\mathrm{B}(p$ value $)$ \\
\hline Constant & $0.626(0.000)$ \\
\hline Promotion \& Advertising & $0.375(0.000)$ \\
\hline Price \& People & $0.355(0.000)$ \\
\hline Charity Image $\quad$ Summary of estimates of regression coefficients \\
\hline $\mathrm{R}$ & $0.123(0.000)$ \\
\hline $\mathrm{R}^{2}$ & 0.692 \\
\hline adjusted $\mathrm{R}^{2}$ & 0.479 \\
\hline VIF statistic & 0.475 \\
\hline F value $(p$ value $)$ & 1.878 \\
\hline Repurchase Intentions $=0.626+0.375$ Promotion \& Advertising +0.355 Price \& People +0.123 Charity Image
\end{tabular}


Table 4.7 Regression results of the effect of service quality on repurchase intentions

\begin{tabular}{|c|c|}
\hline Independent variable & $\mathrm{B}$ ( $p$ value) \\
\hline Constant & $0.259(0.135)$ \\
\hline Service Quality & $0.894(0.000)$ \\
\hline \multicolumn{2}{|c|}{ Summary of estimates of regression coefficients } \\
\hline $\mathrm{R}$ & 0.730 \\
\hline $\mathrm{R}^{2}$ & 0.533 \\
\hline adjusted $\mathrm{R}^{2}$ & 0.532 \\
\hline VIF statistic & 1.815 \\
\hline F value ( $p$ value) & $454.241(0.000)$ \\
\hline
\end{tabular}

\section{Conclusions and Recommendations}

This study aims to investigate the relationships among marketing models, service quality, and customer repurchase intentions from the perspective of life insurance purchase and consumption in Taiwan. The results of this study suggest that demographics do affect the different purchase motivators. Specifically, the finding of consistent significant associations between average monthly income and the three variables investigated might be a good indicator of the importance of customer purchase decisions for the life insurance industry. In this study, the evidence indicates that customers with different average monthly income showed significant differences in the perception of marketing models, service quality, and repurchase intentions. From the data gathered, the higher the earnings, the higher the repurchase intentions.

The results also show that the two variables, marketing models and service quality, are significantly positively correlated with repurchase intentions, and that service quality as compared to marketing models is more positively related to repurchase intentions. More importantly, there is also empirical evidence that service quality has a stronger and more consistent effect on repurchase intentions than does marketing models. Together, these lead to the conclusion that the relationship between service quality and repurchase intentions is stronger than marketing models and repurchase intentions, implying that repurchase intentions are largely influenced by service quality.

The findings of this study provide us with an understanding of the key drivers of consumer repurchase intentions. Improving service quality leads to an increase in repurchase intentions. From a managerial standpoint, in line with Siddiqui and Sharma's (2010) contention, results of this study provide important information on service quality dimensions and their relative importance to the life insurance industry; that is, such information can be used by life insurance companies for adding value to their relationship with current and prospective customers, by performing on differential strategies aimed at improving the service quality. Service quality should remain a primary strategic focus of the industry due to its strong impact on customer repurchase intentions.

\section{References}

Chan, L. L. \& Idris, N. (2017). Validity and reliability of the instrument using exploratory factor analysis and Cronbach's alpha. International Journal of Academic Research in Business and Social Sciences, 7(10), 400-410.

Cooper, R. W. \& Frank, G. L. (2001). Key ethical issues facing the property and casualty insurance: Has a decade made a difference? CPCU Journal, 54 (2), 99-111.

Duncan, T. \& Moriarty, S. E. (1998). A communication-based marketing model for managing relationships. Journal of Marketing, 62(2), 1-13.

Ericson, R. V. \& Doyle, A. (2006). The institutionalization of deceptive sales in life insurance: Five sources of moral risk. British Journal of Criminology, 46(6), 993-1010.

Hellier, P. K., Geursen, G. M., Carr, R. A., Rickard, J. A. (2003), Customer repurchase intention: A general structural equation model. European Journal of Marketing, 37(11/12), 1762-1800.

Jones, M. A., Mothersbaugh, D. L., \& Beatty, S. E. (2000). Switching barriers and repurchase intentions in services. Journal of Retailing, 76(2), 259-274.

Kim, B. (2011), Understanding antecedents of continuance intention in social-networking services, CyberPsychology, Behavior \& Social Networking, 14(4), 199-205.

Kottler, P. (2000). Marketing Management. New Jersey: Prentice Hall. 
Liao, W.N., Tang, T. C., \& Chi, L. C. (2017). A study of applying quality function deployment and service quality model to service quality of credit department of farmers' association: A case study in Taiwan. International Research Journal of Applied Finance, 8(2), 47-69.

Louro, M. J., Pieters, R., \& Zeelenberg, M. (2005). Negative returns on positive emotions: The influence of pride and self-regulatory goals on repurchase decisions. Journal of Consumer Research, 31, 833-840.

MacDonald, E. K. \& Sharp, B. M. (2000). Brand awareness effects on consumer decision making for a common, repeat purchase product: A replication. Journal of Business Research, 48(1), 5-15.

Pallant, J. (2007). SPSS survival manual: A step by step guide to data analysis using SPSS for Windows (3rd ed.), Berkshire: Open University Press.

Parasurman, A., Berry, L. L., \& Zeithzml, V. A. (1988), SERVQUAL: A multiple-item scale for measuring consumer perceptions of service quality. Journal of Retailing, 64, 12-40.

Regan, W. J. (1963). The service revolution. Journal of Marketing, 47, 57-62.

Reza, S. M. \& Iqbal, M. M. (2007). Life Insurance Marketing in Bangladesh. Journal of Business and Economics, 2(2), 87-103.

Schneider, B. (1994). HRM - A service perspective: Towards a customer-focused HRM. International Journal of Service Industry Management, 5(1), 64-76.

Seiders, K., Voss, G. B., Grewal, D., Godfrey, A. L. (2005). Do satisfied customers buy more? Examining moderating influences in a retailing context. Journal of Marketing, 69(4), 26-43.

Sharma, N. \& Patterson, P. G. (1999). The impact of communication effectiveness and service quality on relationship commitment in consumer, professional services. Journal of Services Marketing, 13(2), 151-170.

Siddiqui, M. H. \& Sharma, T. G. (2010). Measuring the customer perceived service quality for life insurance services: An empirical investigation. International Business Research, 3(3), 171-186.

Tang, T. C., Chi, L.C. \& Tsai, C. H. (2020). Brand image and service quality on purchase intentions: Evidence from the chain cram schools in Taiwan. International Journal of Humanities and Applied Social Science, 5(7), forthcoming. DOI: 10.33642/ijhass.v5n7p1

Taylor, S. A. (2001). Assessing the use of regression analysis in examining service recovery in the insurance industry: relating service quality, customer satisfaction and customer trust. Journal of Insurance Issues, 24(1/2), 30-57.

Wheelen, T. L. \& Hunger, J.D. (2008). Concepts in strategic management and business policy. New Jersey: Prentice Hall.

ZeithamI, V. A., \& Bitner, M. J. (2003). Services marketing: Integrating customer focus across the firm. New York: McGraw-Hill.

Zeithaml, V. A., Parasuraman, A., \& Berry, L. L. (1985). Problems and strategies in services marketing. Journal of Marketing, 49, 33-46. 